\title{
CONNOTATIVE MEANING IN THE PROVERBS OF THE BESEMAH LANGUAGE (A SEMATIC STUDY)
}

\author{
Efransyah $^{1}$ \\ ${ }^{1}$ IKIP Siliwangi \\ 1 efransbae@gmail.com
}

\begin{abstract}
Besemah language is identical of a phonem /e/ from indonesian phonem /a/. The language is used in some areas of south Sumatra especially in Lahat district, South Oku district, Bengkulu Province, and Pagar Alam City. This research was aimed to describe the connotative meaning in the proverbs of the Besemah Language. The object of this research was taken from secondary data which is the dictionary of Besemah Language written by Mahdi in 2017. The writer used descriptive qualitative method in this research and some semantic theories both grand and supported theories to analyze the data. The results of this research showed that that the connotative meaning in the proverbs of Besemah Language are having great differences to denotative ones for it depends on individual experience. It means that we will understand the meaning of the proverbs from someone's experience both through the direct story from the older people (anchestors) and witten book/dictionary. Besides, the connotative meaning of the proverbs in Besemah language mostly corelate the meaning of its proverbs to human life such responsibility, social concern, hard work, patience and love.
\end{abstract}

Keywords: Besemah, Language, Meaning, Proverb

\section{INTRODUCTION}

Language is a means of communication that is used to transfer information, ideas, and feelings from one person to another. It is used to communicate both in written and spoken form. As times goes by, the development in communication has increased all over the world, countries or even the tribes. There are many tribes in Indonesia which are spread out in all over regions such as the Javanese tribes, Sundaness, Batakness, Madurese, Besemah, Minangkabau, Buginese tribes and many others. Therefore, the needs for communication among them which have different local languages characteristics create an essential thing to be solved for the existence of those local languages are protected by Indonesian country.

In this research, the writer focused at one of the local language which is Besemah language that mostly used in South Sumatra. According to Aliana as cited in (Saputra, 2014) Besemah Language is used in some areas of south Sumatra especially in Lahat district, South Oku district, Bengkulu Province, and Pagar Alam City. On that time, the people not only the adults but also the young ones, used that language which is inherited from their anchestors but not with the besemah people right now.

As time goes bye, the preservation of Besemah language especially in Pagar Alam city towards extinction fot it breaks way from Lahat district to be autonomous city since June $21^{\text {st }}, 2001$. The language which is identical of phoneme/e/ for example "dimana"/dimane/, "siapa"/siape/, "kemana" /kemane/ tend to be phoneme /o/ "dimana"/dimano/, "siapa"/siapo/ and "kemana" 
/kemano/ as the besemah people feel proud of using it because the phoneme /o/ mostly used by the people who live in south Sumatra especially in a big city (Palembang).

Nowdays, the young generation gradually did not know their native own language. It is not only the meaning of the words, phrase, clause, or sentence but also the meanig of proverbs in Besemah language itself. The purpose of this research is to describe the proverbs meanig of Besemah language in connotative meaning. The writer analyzed the meaning of proverbs in Besemah language as an effort to comprehend the uniqueness of the local language. In analyzing the collected data, the writer used semantic theory from leech as a grand theory and some other supported theories.

\section{Semantics}

The term semantic was mainly refers to the study of language meaning. As one of the braches of linguistics that mainly concerned with how the 'meaning' was conveyed by the linguistics system, semantic is consisting of different unit structures like sentence, phrases, words, morphemes etc. As a study of meaning, semantic relates the language to the various aspects of non-linguistics reality, was also of interest to various disciplines such as philosophy, anthropology, psychology, communication theory etc. According to Leech (1989:61) as cited in Dixon (2010) identifies several types of meanings namely conceptual or denotative meaning, Connotative meaning, Social meaning, Affective meaning, Reflected meaning, Collocative meaning and thematic meaning. These those seven kinds of meaning are differentiated to the three types of lexical meaning. In line with this, Hurford (2007:1) as cited in Husein (2019)states that semantic is the study of meaning in language, whereas lexical relations describe relationship among word meanings.

\section{Conceptual meaning}

Conceptual meaning is the same as denotative meaning or descriptive or cognitive meaning. Compare to the organization and structure to the syntactic and phonological levels of language, conceptual meaning is the primary among the others. The basis of conceptual meaning are the two structural principles that seem to be basis of all linguistics patterning namely the principle of contractiveness and the principle of structure. While the ones by which larger linguistics units are built up out of smaller units, it becomes the second principle. In another hands, it was the principles by which a sentences is analyzed into its constitute parts. The two principles of constituent structure represent the way language was organized.

\section{Connotative meaning}

The meaning was the communicative value as an expression has by virtue of what if refers to over and above its purely conceptual contents is called connotative meaning. These have different features of the referent or denotatum or segment of the real world compare to the conceptual meaning. The different features of the referent few are constrative or criteria features which provide the basic criterion of the correct use of words.

According to Leech's (1981), connotative meaning associates with the linguistics expression one uses or hears that was concerned with the real world experiences. Compare to conceptual meaning, it was peripheral. Varies according to culture, historical periods and experience of the individual makes it relatively unstable. Connotative meaning was indeterminate and open ended for it depends upon the knowledge and beliefs of the speakers and may belong to any characteristics of the referent, real or imaginary as identifies by the speaker. But conceptual meaning consist of a closed set of features which are finite in number. Zgusta (1971) agreed with what Leech calls that social and affective meaning are included under connotation meanwhile Lyon's and others call affective or emotive, meaning as connotation. Odebunmi 
(2001:49) states that connotative meaning depends on "individual experience" ultimately while Yule (1996) emphesize it to the "speaker meaning" essence.

\section{Social and Affective meaning}

Seeing from two aspects of communication which are derived from the situation or environment in which an utterance or sentence was produced in a language, these two meaning are concerned of them. Of these two, convey about the social circumstance of its use in social meaning that was the information of which a piece of language (i.e. a pronunciation variation, a word, phrase, sentence, etc.,). Social meaning was comprehend through different dimension recognition of and level of style within the same language. Affective meaning reflects the speaker's personal feelings which includes the attitude of the listener or his attitude to something the listener was talking about. But in the case of social meaning, leech's includes it not only difference in the use of words or lexemes but also factors of intonation and voice-timber referred to as tone of voice.

\section{Reflective and collocative meaning}

On the lexical level of language, these two types of meaning are due to relation between words or interconnection. They reflected the meaning which arises in cases when a word has multiple conceptual meaning or polysemous, when one sense of a word form part of our response (or reaction) to another sense. The association of a word acquires on account of the meaning of words which tend to occur in its environment is the part of collocative meaing.

\section{Associtaed meaning}

From the six kinds of meaning discussed so for except the conceptual meaning the other five i.e. connotative, social, affective, collative and reflected meaning have something in common. These meaning have variable character and open ended. Clearly, they can not investigated either-this-or-that term. Therefore, Leech group all these under the heading of associative meaning. While conceptual meaning was part of the language common system which is shared by member of the speech community, associative meaning was less stable and varies with the individual's experience.

\section{Thematic meaning}

Thematic meaning was that "the way what was communicated in which a speaker or writer organize the message, in terms of ordering, focus, and emphasis". To highlight information in one part of a sentence, the thematic meaning can also be expressed by means of stress and intonation

\section{METHOD}

The method used in this theory is descriptive qualitative method. The steps are: the first, the writer took the data from secondary data which is Kamus Base Besemah. The second, the writer analyzed the chosen proverb in Besemah Language at lexical and connotative meaning. According to Taylor (1984) as cited in (Efransyah, 2018) "qualitative method makes the researcher develop concepts, insight and understanding from pattern in the data rather than assess preconceived models, hypothesis or theories".

\section{RESULTS AND DISCUSSION}

\section{Results}


In this research the writer found twelve data as follow:

1. Kandang bughuq disighati.

2. Kalu lanang la tue diq nue ame galaq mataghi

3. Tupaq belum masak kuncit la bambur.

4. Sehuma diq setangge.

5. Sape ndaq idup nyintaq nyawe.

6. Luluq augh di pucuk pematang ngikuti angin.

7. Angat-angat tai nganyuq.

8. Janji nunggu kate betaruh.

9. Nunggu mamaq diq lalu.

10. Jangan ndaq lemaq diq betembai.

11. Nyeguti ayam makan jemugh.

12. Amu selikur dide ka mandaq di duwe puluh.

\section{Discussion}

After the writer conducted the library research related to the collecting data, he founf twelve data to be analyzed as follows:

\section{Data 1}

\section{Kandang bughuq disighati.}

Denotatively the proverb kandang bughuq disighati means broken fence is repaired while connotatively the proverb means to make the sibling relation closer. It describes about the family's members who didn't know each other for a long time because of many reasons in the past so when there is a special occasion, they visit each other to know more that they are in fact related by blood.

\section{Data 2}

\section{Kalu lanang la tue diq nue ame galaq mataghi.}

Denotatively the proverb kalu lanang la tue diq nue ame galaq mataghi means the old man is immature when he is just sunbathing. Connotatively it connotes a lazy man who does not want to do anything. It describes about a man who does not like to work at the field or rice field to full fill his family necessities. Usually he count more on his wife to go in early morning.

\section{Data 3}

\section{Tupaq belum masak kuncit la bambur.}

Denotatively the proverb tupaq belum masak kuncit la bambur means the tupaq (kinds of fruits) hasn't been ripe yet but it has already smelled everywhere while connotatively it states about the uncertain news which is scattered everywhere. It describes about someone who easily believes in something new without checking its validity.

\section{Data 4}

\section{Sehuma diq setangge.}

Denotatively the proverb sehuma diq setangge means the same house but has different stairs while connotatively it means disharmonious family. It describes about a family (husband and wife) in disharmonious situation because of any reason both internal and external factors. They live at the same house but became selfish each other when they have to get the dicission to find the solution of the problem between them. Finally, they will decide to do anything on their own way without discussing it together as husband and wife as a solid family. 


\section{Data 5}

\section{Sape ndaq idup nyintaq nyawe.}

Denotatively the proverb Sape ndaq idup nyintaq nyawe means anyone who wants to live, he or she has to work hard while connotatively the it describes about someone who has been mature or adult to be independent but still counts more on his/her life to the family. It does not mean that their family members do not pay attention on them but they do not want to find work for themselves.

\section{Data 6}

\section{Luluq augh di pucuk pematang ngikuti angin.}

Denotatively the proverb Luluq augh di pucuk pematang ngikuti angin means a bamboo which is blown up by wind which will follow where the wind is but connotatively it describes about the people who do not have a stance. They only follow anything what people said without having a stace on their own way and estimating whether it is the right or the wrong action to do fro themselves.

\section{Data 7}

\section{Angat-angat tai ngayuq.}

Denotatively the proverb Angat-angat tai ngayuq means the manure of chicken but connotatively it states about someone's unstable spirit which is only higher in the beginning but gradually lower at the ends. It describe about inconsistent people to do anything.

\section{Data 8}

\section{Janji nunggu kate betaruh.}

Denotatively the proverb Janji nunggu kate betaruh means the promise is waiting its responsibility but connotatively it describes about the people that must be carefull of their statements or utterences because they have to be responsible of them. It states about how important the promise is. So, when we make it to anyone, we have to pay attention and always remember it because someone will ask for the proof someday.

\section{Data 9}

\section{Nunggu mamaq diq lalu.}

Denotatively the proverb Nunggu mamaq diq lalu means about waiting someone that does not pass on that way but connotatively it describes about disappointment. One waits for something is impossible to be waited. So we have to make sure everything clearly before making an appointment.

\section{Data 10}

\section{Jangan ndaq lemaq diq betembai.}

Denotatively the proverb Jangan ndaq lemaq diq betembai means do not think to be happy without starting to work hard but connotatively it states about the people who want to live happily without efforts. It describes about lazy people who only imagine to live happily but do not do anything to make their dream come true.

\section{Data 11}

\section{Nyeguti ayam makan jemugh.}

Denotatively the proverb Nyeguti ayam makan jemugh means regretting chicken eats the rice but connotatively it states about regretting misfortune or lost something due to his or her own fault. It describes about some people who do not be sincere with the destiny happed to them. They only complain without evaluating and trying hard to be better for their future life. 


\section{Data 12}

\section{Amu selikur dide ka mandaq di duwe puluh.}

Denotatively the proverb Amu selikur dide ka mandaq di duwe puluh means if selikur or twenty one, it will not stop atnumber twenty but connotatively it states that when it is our fate, a fortune would be achieved by trying hard. It describes about getting sincere of God's decision as a human being because we just try to work hard and Allah will determine everything. We can do anything hardly to get our success and may not give up of the failures for it is the delleyed real success in the future.

\section{CONCLUSION}

This research focuses on the connotative meaning in the proverbs of the Besemah Language as an effort to comprehend the uniqueness of local language. From the twelve collected data which had been analyzed in connotative meaning, they can be concluded that the connotative meaning in the proverbs of Besemah Language are having great differences to denotative ones for it depends on individual experience. It means that we will understand the meaning of the proverbs from someone's experience both through the direct story from the older people (anchestors) and witten book/dictionary. Besides, the connotative meaning of the proverbs in Besemah language mostly corelate the meaning of its proverbs to human life such responsibility, social concern, hard work, patience and love.

\section{ACKNOWLEDGMENTS}

All praise to Allah for helping the author to finish this research. The writer wants to express his gratitude to his beloved family and best friends who had supported him in completing this research.

\section{REFERENCES}

Dixon, R. M. (2010). Where Have All The Adjectives Gone?: And Other Essays In Semantics And Syntax (Vol. 107). Walter De Gruyter.

Efransyah. (2018). Analyzing Thematic Structure In Indonesian Folktales In English Version: A Systemic Functional Grammar (Sfg). Efransyah. (2018). Analyzing Thematic Structure In Indonesian Folktales In English Version: A Systemic Functional Grammar (Sfg). Project (Professional Journal Of English Education), 1(2), 85-94.

Husein, N. M. (2019). A Semantic Analysis Of Lexical Relations In Muse Selected Song Lyrics. (Doctoral Dissertation, Iain Salatiga).

Lyons, J., \& John, L. (1995). Linguistic Semantics: An Introduction. Cambridge University Press.

Mahdi, S. (2017). Compounding Of Basemah Language: An Effort To Understand The Uniqueness Of Local Languages.

Saputra, H. D. (2014). Deiksis dalam Bahasa Besemah. Deepublish.

Usman, J., Mustafa, L. J., \& AGU, M. N. (2013). Proverb as Determinant of Cultural Identity: The Imperative of the Three Regional Languages in Nigeria. IMPACT: International Journal of Research in Humanities, Arts and Literature, 1, 47-58.

Yule, G. (n.d.). A Study of Language (2nd ed). Cambridge: Cambridge University Press.

Zgusta, L. (1971). Manual of Lexicography. Prague: Publishing House of the Czechoslovak Academy of Science. 